Final MS version.

Published online in the British Journal of Religious Education, June 2018, pp.1-12.

https://doi.org/10.1080/01416200.2018.1478276

\title{
Choosing a faith school in Leicester: admissions criteria, diversity and choice
}

\author{
Mairi Levitt and Linda Woodhead \\ Department of Politics Philosophy and Religion, Lancaster University, Lancaster
}

ABSTRACT Religion in Britain is in overall decline and 'no religion' is growing, but one-third of schools in the state sector in England and Wales are 'schools with a religious designation' ('faith schools'). Historically, these were Protestant and Catholic Church schools, but new faith schools have been established by Churches and other faiths. Governments of all parties have encouraged this development, chiefly on the grounds of increased parental choice and improved quality. The research presented here provides evidence about the operation of faith schools in the English city of Leicester in 2016, particularly from the perspective of those choosing a school. The main objectives are to (1) indicate the diversity of faith schools, (2) show how they present themselves to those looking for a school: their admission requirements and level of educational attainment and (3) reflect on the claim that faith schooling offers more and better choice and quality. Leicester is selected for its size and diversity; it is small enough to study with the resources available to us and is one of the most multiethnic and multifaith urban areas in England. Research was carried out between February and July 2016 and offers a snapshot from that year.

For reasons to do with the Churches' historic role in providing education, a significant proportion of the state-funded schools in England are schools with a religious designation around a third of all schools. (For the sake of brevity, and because this is now the common parlance including in government circles, we will use the term 'faith school' for such schools but display the diversity which the category can hide.) Despite the fact that Britain is experiencing a rapid growth of 'no religion', government policy from New Labour (1997) onwards has supported the state funding of existing faith schools and encouraged the establishment of new faith schools, most of which are academies or free schools which do not come under the control of a local authority. A consultation paper published early in the government of Theresa May showed that it wished to support and encourage this direction of travel (Department for Education 2016, 30-35).

In recognition of the importance of religion in the school system of England and Wales, in 2015 the former Education Secretary, Charles Clarke, and Linda Woodhead published a pamphlet entitled A New Settlement: Religion in Schools (Clarke and Woodhead 2015). It reviews the main areas of education settlement regarding religion and schools arrived at in 
legislation in 1944 and largely unchanged since then and makes recommendations about reforms. The intention was to stimulate informed debate and to hold consultations which will lead to a revised version of the recommendations in 2017, and ultimately to change and improvement. In the course of the debates and conversations, the need for more evidence in a number of areas including faith schools has become clear.

This article is one response. Its purpose is not to enter into the ongoing and often heated controversy about the very principle of the state-funded faith schools ${ }^{1}$ but to help ground and inform the debate by focussing on one aspect of the actual provision of such schooling. The aim is to consider, from the point of view of someone choosing a school in Leicester in 2016, how the faith school sector presents itself - especially in terms of admissions and attainment, two key elements in making a choice - and what this tells us about the contribution of faith schools to the overall ecology of choice in schooling in the city. The article has three related objectives. First, to gauge the range, types and diversity of statefunded faith schools. Second, to see what these schools offer parents and children: how they present themselves to those who are looking for a school, what their admission requirements are, and what level of educational attainment they achieve. Third, by way of conclusion, to reflect on whether the faith-school sector in this city offers parents choices and reflects their religious and cultural diversity and that of their children. To our knowledge, this is the first research carried out on how faith schools actually operate with regard to selection within the wider ecology of schooling in a city, and is intended to offer a contribution to knowledge, with relevance for policy.

\section{Locality and methods}

Leicester was chosen for the study because, although we did not have extensive prior knowledge of its schools, it matched our criteria of selection. It has a diverse population and a proud identity as a multifaith and multicultural city with corresponding diversity in faith school provision. It is small enough to study with the resources available to us but large enough to display variety: with a population of 329,839 , Leicester is the 11th most populous urban area in England but one of the most multi-ethnic and multifaith, with a school sector reflecting that profile. It is also appropriately self-contained in terms of schooling - we ruled out multifaith London boroughs, for example, because large numbers of pupils travel to state-funded schools in other parts of the city.

Central to the research was the task of mapping the faith schools of the city, with complete coverage of the domain being essential. Given the ready availability of information online due in part to legal requirements on schools - it proved possible to rely on desk-based research. The information presented here is drawn from the extensive data that are freely available to parents choosing a school in the city of Leicester. These include the local authority and individual school websites, inspection reports (both from general inspections and inspections of collective worship and religious education in faith schools) and examination results and other school data published annually by the government (Gov.uk 2015). The research was carried out between February and July 2016 and the information was current at that time. 
Faith schools and religious diversity

The population of Leicester is more diverse and younger than England as a whole. Under half of the population (45\%) are white British, and a quarter are 20 years old or younger, according to the 2011 census. It is in the top $10 \%$ of the most deprived local authorities in England, coming 21st out of 326 (Leicester City Council 2015b).

The religious make-up of the population of Leicester according to the 2011 census (Census 2011) was one-third Christian, $23 \%$ no religion, $19 \%$ Muslim and $15 \%$ Hindu. In England as a whole, the equivalent figures from the census are $59 \%$ Christian, $25 \%$ no religion, $5 \%$ Muslim, 1.5\% Hindu. For various reasons, including the fact that the question is optional and filled in by the head of household, the census undercounts 'no religion'. Representativesample surveys including the British Social Attitudes Survey and a series of surveys carried out by Woodhead with YouGov find the share of no religion in Britain (and separately in England, Wales and Scotland - there is little variation) to be around $50 \%$ of the population, and higher amongst younger generations (the data are presented and analysed in Woodhead 2016; Bullivant 2017; for Scotland and the Scottish Social Attitudes Survey see Bruce 2014). Leaving this latter point aside for now, however, and because there are no accurate representative surveys of the religious population of Leicester, we can use the census figures to gauge the proportions by religion of children entering schools, making the assumption that the age distribution within each group is the same as it is in the national population, as in Table 1. The census does not break down 'Christian' by denomination, but in England as a whole, self-identified members of the Church of England make up around $30 \%$ of the population and Roman Catholics around $10 \%$.

Table 1

Table 1. Proportions of children in Leicester aged 10-14 by religion (Census 2011)

\begin{tabular}{|l|l|l|l|l|l|l|}
\hline Christian & $\begin{array}{l}\text { No } \\
\text { religion }\end{array}$ & Muslim & Hindu & Sikh & Buddhist & $\begin{array}{l}\text { Other } \\
\text { religion }\end{array}$ \\
\hline $29 \%$ & $24 \%$ & $28 \%$ & $12 \%$ & $5 \%$ & $0.2 \%$ & $3 \%$ \\
\hline
\end{tabular}

For the reasons just explained this probably underestimates the true proportion of 'no religion' children.

Leicester City has state-funded faith schools designated as Church of England, Roman Catholic, Hindu, Sikh and Muslim. As detailed below, several - both Christian and other faith - have been opened in the first quarter of the twenty-first century.

In England as a whole, state-funded faith schools make up $37 \%$ of primary schools but educate $29 \%$ of primary age children, due to the number of small Church of England schools especially in rural areas. There has been an increase of $1 \%$ in faith school pupil numbers since 2000 . At secondary level, $19 \%$ of schools have a religious designation, educating $18 \%$ of the age group, an increase of $3 \%$ in pupil numbers since 2000 (Clarke and Woodhead 
2015, 17 and Long and Bolton 2015, 16). A table displaying the numbers and categories of faith and non-faith schools in England is included in Appendix 4.

\section{Diversity of primary schools in Leicester}

There are 13 state-funded faith schools for primary age children in Leicester including those designated as voluntary aided (VA), voluntary controlled (VC), academies (including one 416 academy) and two free schools (for more information see Appendix 1). (VA schools are those where the state/local authority supplies funding but a religious foundation or trust [mainly church-related] has significant influence in the running of the school; VC schools are faith [mainly church] schools which are both funded and largely controlled by the state/the local authority. For more information see Appendix 4.) Together, these schools offer places to $16 \%$ of children starting school in Leicester. This is below the average for England as a whole (Leicester City Council 2016a, 18-28). The 6 Catholic primary schools have the highest combined admissions figure at 290 children, the 5 Church of England schools have 261, the Hindu and Sikh schools 60 pupils each. The 13 faith primaries break down as follows (Table 2):

Table 2. Primary Schools in Leicester by religious designation

\begin{tabular}{|l|c|c|}
\hline Type of school & $\begin{array}{l}\text { Number of } \\
\text { schools }\end{array}$ & Religious designation \\
\hline Voluntary Aided & 6 & 3 RC \\
\hline Academy & 4 & 1 CofE \\
& & 3 RC \\
\hline Free School & 2 & 1 Hindu \\
& & I Sikh \\
\hline Voluntary Controlled & 1 & 1 CofE \\
\hline
\end{tabular}

\section{Diversity of secondary schools in Leicester}

There are 5 secondary faith schools in Leicester out of a total of 18 secondary schools. Full details are provided in Appendix 2. The break down of the schools is as follows (Table 3):

Table 3. Secondary Schools in Leicester by religious designation

\begin{tabular}{|l|l|l|}
\hline Type of School & Number of Schools & Religious Designation \\
\hline Voluntary Aided & 4 & 2 RC \\
& & 2 Muslim \\
\hline
\end{tabular}




\begin{tabular}{|l|l|l|}
\hline Academy & 1 & 1 Church of England \\
\hline
\end{tabular}

The combined published admission number for all the secondary faith schools is 600 pupils which represents $17 \%$ of the total number of places in non-fee paying faith secondary schools (Leicester City Council 2016b). This is close to the average figure for faith secondary schools in England as a whole (18\% of pupils and $19 \%$ of schools, Clarke and Woodhead 2015, 17).

Clearly, the diversity of faith schools in Leicester does not accurately reflect the diversity of faiths in contemporary Britain. This is especially clear in a multicultural city like Leicester but is also true for England as a whole, and is a legacy of the Christian past. In terms of the proportions of those who identify with a faith in Leicester (children as well as adults) and the number of school places available in corresponding faith schools, it is in relation to Muslim, Hindu and Sikh schools that there is the greatest undersupply. In terms of all who identify as Christians, whether practising or not, there is also an undersupply of church schools, though the declining number of Christians may in time correct this.

Admissions policies and academic rankings of faith schools in Leicester

All parents in Leicester can apply for three schools at primary or secondary level and are advised to use all three choices (Leicester City Council 2016a; Leicester City Council 2016b). In admissions, all state-funded schools are required to give priority to 'looked-after' and 'previously looked-after' children, but some faith schools subordinate this to faith criteria (looked-after children are those who are the care of a local authority). In Leicester, the Church of England VA and VC primaries give first priority to any child in this category whereas the Catholic primaries give first priority to Catholic children and other 'looked-after children' are fourth or sixth in the list of criteria. The Hindu and Sikh free schools separate out community and faith places and give first priority to looked-after children from 'practising Hindu families' or 'of the Sikh faith' for their faith places.

None of the secondary faith schools received the highest grade of outstanding in their last Ofsted report. ${ }^{2}$ The appendices give full details of the assessments and ranking of the primary and secondary faith schools and the non-faith secondary schools. In terms of ranking on GCSE (General Certificate of Secondary Education) results, the faith secondary schools are ranked as follows (Table 4):

Table 4. Ranking of faith secondary schools on GCSE results and Ofsted inspection

\begin{tabular}{|l|l|l|}
\hline School & Ranking & Ofsted inspection grade \\
\hline Madani Girls (VA, Muslim) & 1 st & 2 \\
\hline English Martyrs (VA RC) & 6 th & 2 \\
\hline St Paul's (VA RC) & 7 th & 3 \\
\hline Madani Boys (VA Muslim) & $8^{\text {th }}$ & 2 \\
\hline
\end{tabular}




\begin{tabular}{|l|l|l|}
\hline Tudor Grange (Academy CofE) & $17^{\text {th }}$ & 4 \\
\hline
\end{tabular}

\section{Primary schools}

\section{Church of England primary schools}

In the three VA Church of England primary schools, the admissions criteria are, first, having a sibling already at the school and, second, having a parent/guardian employed the school. The faith criteria come next and read; 'an active member of a church within the Church of England or of another Christian church belonging to Churches Together in England'. Parents are asked to provide details of the church and a letter of support from the minister or faith leader. The final criterion is 'active member of a place of worship within another faith'. These criteria are said to be cumulative. The example given on Hope Hamilton school's supplementary information form (SIF) was that a sibling with a letter of support from a minister or faith leader would come before a sibling without such a letter (Hope Hamilton VA primary school). The only Church of England VC school in Leicester, St. Barnabas, has faith as its fourth criteria: 'children whose parents are basing their application on religious convictions' (Leicester City Council 2016a).

All these schools are ethnically diverse. At St. John the Baptist, a VA school, according to the Section 48 inspection, 'half the pupils are of White British heritage and the remainder from other ethnic backgrounds and religious groups' (Diocese of Leicester). The percentage of ethnic minority children at the other two VA primaries is 75\% (Hope Hamilton), $40 \%$ (Belgrave St. Peter's) and 'nearly all' children at the VC school, St. Barnabas (Diocese of Leicester, St. Barnabas Ofsted 2013). At St. Barnabas, 51\% of the children are Muslim, 26\% Hindu and $12 \%$ Sikh (ibid, Section 48 inspection, 2015). None of these schools is graded as outstanding; three are graded as good and one as requiring improvement.

There is also an Enterprise Academy that is jointly sponsored by Sir David Samworth and the (Anglican) Bishop of Leicester. The academy was purpose built in 2007 and takes children from age 4 to 16 . Most of the intake has white British background, reflecting the local area, with above average proportions of disadvantaged children and children with special educational needs. The Leicester City Council admissions information does not give any indication that the school has any connection to the Diocese of Leicester and nor do the admissions criteria for primary or secondary age group (Leicester City Council 2016a; Leicester City Council 2016b, 40f). The school was judged inadequate in a 2015 Ofsted inspection and also in the Section 48 inspection in 2014 (Diocese of Leicester Diocesan Board of Education). From 1 January 2016, the school has become a member of the Tudor Grange Academies Trust and is described by the Principal on the website home page as a Church of England school (Tudor Grange Samworth Academy). However, the admissions criteria for 2016-17 remain the same as for non-faith or 'community' schools.

Roman Catholic primary schools 
Selection criteria come into play if a school is oversubscribed, that is if there are more applications for pupil places than there are places. In the case of oversubscription, the selection criteria which will then be applied in all six Catholic schools, listed in Appendix 1, prioritise Catholic children (looked-after and siblings), followed by the ranked criteria below:

1. Child is a baptised Catholic - evidence required is a copy of the baptism certificate.

2. Child baptised in another Christian denomination and has been received into the Catholic faith (baptism certificate and a written statement or certificate from a Catholic priest).

3. Child is being prepared for Catholic baptism on a recognised course - written statement verifying this from a Catholic priest.

4. Child baptised or dedicated in another Christian denomination which belongs to 'Churches Together in England' (copy of certificate).

5. Child is a member of another faith - copy of baptism or dedication certificate or verification by a religious leader (Leicester City Council 2016a, 29).

It is also stated that priority will be given to those who have submitted a 'mass verification form' to show that they attend mass weekly. According to the outgoing Schools'

Adjudicator, Elizabeth Passmore, making a general point in 2016, catechumens cannot have priority 'above non-Catholic children as catechumens are not (yet) Catholics' (making criterion 3 above invalid).

The Catholic primary schools ranged from 'outstanding' to 'requires improvement' in their most recent Ofsted, all were ethnically diverse and some were more diverse than the local population as a whole. The percentage of Catholic children, where figures were given, ranged from a minority to almost all. Since schools seen as desirable by parents are more likely to be oversubscribed and thus applying faith criteria, this percentage was correlated with the educational standard and the percentage of pupils eligible for the pupil premium for disadvantaged children. For example, Holy Cross, graded as 'requires improvement' in 2014 , had $45 \%$ baptised Catholic, $25 \%$ other Christian denominations and $28 \%$ no religion. St. Patrick's, graded as good, had 69\% baptised Catholic, and at Christ the King, graded outstanding, almost all children were baptised Catholic and transfer to a Catholic secondary school. Whereas nearly half the pupils at Holy Cross were eligible for the pupil premium, only $8.8 \%$ were eligible at Christ the King. The percentage of pupils from minority ethnic backgrounds for these three schools was half at Holy Cross, three quarters at St. Patrick's and half at Christ the King (Nottingham Roman Catholic Diocese Education).

The three voluntary academies had a religious designation before converting to academy status and so may select up to $100 \%$ of the intake by faith criteria. The same pattern was apparent in these schools with St. Thomas More, graded outstanding by Ofsted, having $91 \%$ baptised Catholic pupils and only $6.5 \%$ of pupils eligible for the pupil premium, reflecting the area in which it is situated (Nottingham Roman Catholic Diocese). Sacred Heart Voluntary Academy has a majority of ethnic minority children, a diversity of faiths and above-average numbers receiving the pupil premium.

Free schools with a religious designation 
Free schools are required to ensure, if oversubscribed, that 'at least $50 \%$ of the intake is admitted without reference to faith' (Long and Bolton 2015, 6). Both the Hindu and Sikh free schools have an intake of 60 , with 30 places allocated by faith criteria and 30 community places, as required by law. If one category is undersubscribed, the school may admit from the other. There could therefore be any proportion of children from the designated faith at a free school, up to $100 \%$ if there are no applications for the community places and less than $50 \%$ if the faith places are not filled. It is likely to be difficult to attract applicants from outside a minority faith unless the free school has established a good reputation, thus faith places are likely to exceed $50 \%$. This tendency may be reinforced by the publication of rigorous faith criteria for admissions, even if they are not applicable to community places.

\section{Krishna Avanti School}

On the school website for Krishna Avanti School, opened September 2011, there is a section on Visions and Values stating that: 'Avanti schools are Hindu faith schools which welcome children from all backgrounds', 'the nature of Collective Worship and Religious Studies will be broadly reflective of the practices and teachings of ISKCON' (Krishna Avanti Primary School). The admissions policy states that: 'We ask all parents applying for a place here to respect this ethos and its importance to the school community. This does not affect the right of parents who are not of the faith of this school to apply for and be considered for a place here' (op cit). For faith places, lookedafter children from practising Hindu families have first priority followed by '(2) Up to 10 Children from practising ISKCON families, who worship at an ISKCON centre (3) Children from other practising Hindu families ... who live the shortest distance to school gate (measured in a straight line) (sic)' (Leicester City Council 2016a, 40).

The SIF on the school website asks for an official temple stamp and certification that the family are practising Hindus 'who follow all the key tenets of the faith as practised by our Temple' or (second) cannot verify that the family follow the key tenets 'but they do attend the Temple either regularly or irregularly' (Krishna Avanti Primary School). The first Ofsted inspection reported that most children are from an Asian or British Asian background.

\section{Sikh free school - Falcons Primary School}

The school opened in October 2014. For the 30 places for children of the Sikh faith, the oversubscription criteria read: 'Faith is defined as any child who, with or without their family, is a practising member of the Sikh faith. ... If applying under the Sikh criteria please ensure you email or post a letter from a Gurdwara confirming the applicant has a belief in the teachings of the 10 Sikh Gurus and the Guru Granth Sahib JI and that they regularly attend a Gurdwara' (Falcons Primary School). Falcons had not yet had an Ofsted or Section 48 inspection but the school website reported that $24 \%$ of the children were from non-Sikh backgrounds.

Secondary schools

Church of England Academy 
As discussed in relation to primary schooling above, there is one all-age academy with a Church of England designation but no faith criteria for admissions. The academy opened in 2007 and incorporates an Anglican Church on the site. The school stood out as having the highest proportion of pupils eligible for the pupil premium at both primary and secondary level, low levels of attainment and a largely white British intake. As Table 4 shows, for attainment at GCSE, it was 17th out of the 18 secondary schools in Leicester and it was graded as inadequate by Ofsted (Leicester Diocesan Board of Education, Samworth Enterprise Academy). Although the school's Church of England identity is now prominent on its website, the 'shared ethos' and 'key values' of the Tudor Grange Academy Trust, to which the school now belongs, do not seem to refer to any faith/ religious basis since other schools in the trust are not faith schools (Tudor Grange Academy Trust). The school had places for all applicants.

\section{Catholic VA secondary schools}

The statement on admissions for all Catholic schools in the diocese reads, 'places are available for students from other [non-Roman Catholic] backgrounds whose parents wish them to be educated in a Catholic environment' but also that children of Catholic families have priority. In the admissions criteria, looked-after or previously looked-after children who are 'baptised Catholic pupils' are ranked first and other looked-after children 'who are not Catholic' third (Leicester City Council 2016b). The Catholic schools: '. . . ask all parents applying for a place to respect this ethos and its importance to the school community. This does not affect the right of parents who are not of the faith of these schools to apply for and to be considered for places' (English Martyrs' Catholic School Admissions Policy).

The two VA Catholic schools in Leicester City have the same SIF for those applying under faith criteria. The list of criteria is the same as those given earlier for Catholic primary schools. The current admission policy for the Catholic secondary schools prioritises Catholic children from all backgrounds, stating: 'We are mindful of the mission of the Church to welcome those who are disadvantaged or marginalised. In particular, we continue to welcome children of families from other countries who have made their home in Leicestershire and the Diocese of Nottingham' (Diocese of Nottingham Education Service 2015).

In 2013, half of St. Paul's pupils were white British and half came from a 'wide range of ethnic minority groups', $65 \%$ of pupils were Catholic, $17 \%$ from other Christian faiths and $7 \%$ from other world faiths (Nottingham Roman Catholic Diocese Education [click on school name for section 48 and Ofsted inspection reports]). Having previously been graded as 'good', the school was graded as 'requires improvement' in an Ofsted inspection December 2015 (ibid, Ofsted 2016b). At the other Catholic secondary school, English Martyrs', just over half of all pupils were white British in 2014 (ibid), 74\% were baptised Catholics, 18\% were other Christian, $6 \%$ other world faiths and $2 \%$ no religion (Nottingham Roman Catholic Diocese Education [click on school name for section 48 and Ofsted inspection reports]). As Figure 4 shows, English Martyrs' was graded as good by Ofsted in 2014. Both Catholic schools were graded outstanding in their last Diocesan Denominational inspections. 


\section{Muslim VA secondary schools}

The Madani Schools Federation is located in purpose-built premises, dating from 2007, which have operated as separate boys and girls 11-16 schools since September 2012. The girls' school has the highest GCSE examination results of all state-funded schools in Leicester City: 78\% of girls achieved 5 or more A-C GCSEs including English and maths in 2015 (55\% in the boys' school) (Gov.uk 2015). At both schools, looked-after and previously looked-after Muslim children 'who meet the religious practice test' (quoted in points 1-4 below) are ranked first in the oversubscription criteria and other looked-after children are ranked fifth. The Mission statement reads

Our core values will help learners to become confident in their identity as British Muslims with an enduring desire to perform their religious duties, live in harmony with fellow citizens and contribute positively to the social, political and economic well-being of their country. (Madani School Mission Statement)

The admissions policy for both schools states that each school

aims to provide education for all its pupils in an Islamic environment where Islamic values and practice permeate every aspect of the school's activity. We ask all parents applying for a place for their child, whether they are from the Islamic faith, another faith or none, to respect this ethos and its importance to the school community. (Madani Girls School 2016)

The SIF, on each school's website, states that all questions have to be answered in the affirmative or it will be treated as a non-faith application. Parents are asked to confirm that they are 'bringing up the applicant in the Muslim faith'. The next section on religious practice is to be completed by an official Imam in the presence of the parent/carer answering 'yes' or 'no' to the following questions:

1) I confirm that the child adheres to all of the following principles of Islam: o Belief in the oneness of God (Tawhid) o Belief in the finality of the Prophet Muhammad, peace be upon him (P.B.U.H.) o Respect of all the companions of the Prophet Muhammad (P.B.U.H.) o Accepting the Shahadah (proclamation of faith)

2) I confirm that to my knowledge (or that the parent has directly confirmed to me) that, whenever possible, the child prays 5 times a day

3) I confirm that to my knowledge (or that the parent has directly confirmed to me) that the child fasts during the month of Ramadan

4) In my opinion the child follows the Islamic code of dressing by dressing appropriately and modestly

If there are exceptional circumstances;

The Imam is asked to indicate (if appropriate) which criteria the applicant cannot meet for any exceptional reason and whether and why the Imam considers them suitable for admission as to the school as a practising Muslim (Madani School Federation) 
The emphasis in these criteria is on the child's belief and practice. Both Madani Federation schools were said, in their Section 48 reports, to attract 'pupils of Muslim faith from different backgrounds'; there was no reference to pupils of other faiths or none (AMS UK 2014). In the first intake, it was reported that no non-Muslims had applied and the two schools later dropped the, self-imposed, reservation of $10 \%$ of places for non-Muslims (BBC Leicester 2007). Both schools were graded as good in their most recent Ofsted inspection and received the top grade in the Section 48 inspection by the Association of Muslim Schools, UK (Ofsted 2013; Ofsted 2016c; AMS UK 2014).

\section{State-funded secondary schools without a religious designation}

The 13 secondary schools without a religious designation had combined admissions of 2985 (Leicester City Council 2016b). All, whether Community, Trust or the new Academy, had the same oversubscription criteria for the 2016-17 intake which, after looked-after children and children subject to a child protection order, prioritised children in the catchment area, with those with siblings in years 8-10 taken first. For children outside the catchment area, those with siblings in years 8-10 came first followed by those fleeing domestic violence and finally any other children whose parents requested a place (Leicester City Council 2016b, 11). Four of the schools had an Ofsted outstanding grade at the last inspection. The catchment areas could vary considerably from year to year; for example, the distance from home to school of the last pupil admitted to Moat College was $0.84 \mathrm{mi}$ in $2014-15$ but $3.46 \mathrm{mi}$ in 2015-16. There was one girls' school and one boys' school and the rest were mixed gender schools.

As shown in Appendix 3, there is considerable diversity on educational measures. Schools with the best results on the GCSE measures were the most oversubscribed and had the smallest catchment areas. The two schools that had fewer preferences than the number of places available were ranked 18th (the lowest of all schools) and 13th on GCSE results, but both had below the average percentage of children eligible for the pupil premium. The pupil premium gives additional funding to the school for each pupil who is deemed to be disadvantaged; on average, $39 \%$ of pupils at Leicester's non-faith secondary schools were eligible.

\section{$\underline{\text { Independent schools }}$}

For more affluent parents, the availability of independent fee-paying day schools increases the choices available for their child's education. There are schools that fit into the traditional model that select academically, and, due to the fees, on socio-economic status, but less often by religious criteria. However, in Leicester, there are also a large number of mainly small schools with a strong faith identity and relatively low fees, making them accessible to a wider group of parents.

Among the 'traditional' independent day schools are Leicester Grammar School Trust and Leicester High School for Girls, both are academically selective and have a Christian foundation/Christian ethos but no religious criteria for admissions. Leicester Grammar School's fees for 2015-16 were £12,342 p.a. at secondary level and Leicester High School for Girls charged up to $£ 11,610$ p.a. depending on the school year. Their intake was reported in inspections to be from business and professional families, with over one-third of the 
Grammar school pupils and a majority at the high school being from minority ethnic groups (Independent Schools Inspectorate 2011; Independent Schools Inspectorate 2015a). There is also a Catholic day and boarding co-ed school (Ratcliffe College); 'the Catholic faith permeates the school and lends it much of its character' (Independent Schools Inspectorate 2015b, 4.4). Nevertheless, the faith criteria are not stringent, with 'priority to Catholic families and those sympathetic with the Catholic ethos' (Ratcliffe College).

In the second category of independent schools, there are many schools with strong faith identities and relatively low fees. Emmanuel Christian school provides a 'Bible based Christian education' and had 43 pupils in January 2015, age 4-16, with fees charged according to income from $£ 1500-4000$ p.a. (Emmanuel School). Ten independent schools in Leicester are listed in the Association of Muslim schools directory (AMS UK). For example, Jameah Girls Academy takes girls from age 7 to 16 years old and charged $£ 2300$ p.a. in 2015 (Jameah Girls Academy). The percentage gaining 5 GCSEs grades A* $-C$ was $86 \%$ (Telegraph GCSE Results 2015). Darul Uloom, which prepares male students to become Imams or Islamic theologians, charged $£ 1800$ p.a. for day pupils in 2015 (Darul Uloom) and had a $100 \%$ pass rate for 5 GCSEs including English and maths at grades $A^{*}-C$ (Telegraph GCSE Results 2015). Many of the smaller faith schools had been inspected by Bridges Schools Inspectorate and most were downgraded when re-inspected by Ofsted (Wilshaw 2015). For example, Al-Aqsa School, Emmanuel Christian school and Jameah Girls' Academy were graded as requiring improvement in 2015 (Ofsted 2015a; Ofsted 2015b; Ofsted 2015c) and Leicester Islamic Academy and Leicester International School were both graded inadequate in 2015 inspections (Ofsted 2015d; Ofsted 2015e). However, Al Islamia Institute, a primary school, was graded as good (Ofsted 2016a).

\section{Diversity and choice}

For parents who do not consider their local school to be good enough, the chances are that a preferred school will be popular and oversubscribed. Not surprisingly, schools with the highest percentage achieving 5+ GCSEs including English and maths at grade $\mathrm{C}$ or above were the most oversubscribed. As the appendices show, the percentage achieving that GCSE measure varies from a quarter to three-quarters of the year group in each school. The performance of schools is negatively correlated with socio-economic factors such as the proportion of children eligible for free school meals.

A recent Department for Education report divided schools by performance in Scholastic Aptitude Tests (assessments carried out in primary schools) and GCSEs (the main assessments carried out in secondary schools at age 16) and found that house prices are higher in areas around the top performing schools than in the surrounding areas (Department for Education 2017). Data from a YouGov survey of parents with a child attending school asked if they had themselves used 'particular strategies to get into a good school': $20 \%$ reported moving into an area with good schools and $14 \%$ had moved into the catchment area of a specific school (Francis and Hutchings 2013).

For the Leicester parent seeking an alternative to their local school, there are state-funded faith schools for those who are able or willing to meet the admissions criteria. This is the 
obvious sense in which faith schools increase choice. However, as we have seen, faith schools in Leicester are highly variable in quality running the gamut from the highest to the lowest grades in the most recent Ofsted inspections.

If considering a primary school, six non-faith primary schools and two Catholic primary schools have the highest Ofsted inspection grade of outstanding. At the other end of the spectrum, nine of the non-faith primary schools and two faith schools were graded as 'requiring improvement', and one faith and one non-faith school were graded inadequate (Gov.uk). Looking at children achieving the expected level in the key stage 2 tests, there are no results as yet for the Sikh and Hindu primary schools, but the Catholic and Church of England schools could not be said to be academically better than non-faith schools. Taking the primary schools for which these results are available, and excluding special schools, three Catholic schools are above the midway point in the league tables for these tests and three are below, while two Church of England school are above and three below (Gov.uk 2015).

At primary level in Leicester, a faith school can nevertheless provide an additional choice for parents who are willing to accept the school ethos, regardless of any religious practice. The exception is significant: the highest performing Catholic primary school in which almost all children are at least baptised Catholics. The two free schools in theory provide an additional choice for any parent because they currently have to take half their intake without regard to faith criteria if there are applications. Figures were not available for the Hindu school but the Sikh free school was reported to have $24 \%$ from non-Sikh backgrounds (Falcons Primary School Section).

At secondary level, faith schools do better. Four of the top 10 state-funded schools for GCSE performance are faith schools (out of the 5 faith schools in total) despite 1 of the 4, St. Paul's Roman Catholic secondary school, receiving an 'inadequate' Ofsted grading (Appendix 2). The top performing VA Muslim girls' school is oversubscribed and so can select only practising Muslim pupils using rigorous criteria of childhood belief and practice. The intake at the Catholic secondary schools is not exclusively baptised Catholic, but the next largest group admitted to Roman Catholic schools are from other Christian backgrounds. The two Catholic schools have the lowest percentage of pupils eligible for the pupil premium of all Leicester secondary schools (although the average for faith schools in total is the same as for non-faith schools). This suggests that the religious designation in the case of these Catholic schools also allows a degree of socio-economic selection, with more affluent parents benefitting. By contrast, the one Church of England secondary school has the highest percentage eligible for pupil premium of all secondary schools and is undersubscribed. This school has relatively low performance at GCSE, required improvement in the Ofsted inspection and, according to a report in the local paper, had a high truancy rate (Leicester Mercury 2016a). This seems to illustrate the finding that the criteria of a good school will come before faith considerations for most parents.

Do parents want to choose a faith school? 
Before concluding, it is relevant to note that not all parents may wish to send their child to a faith school, even if they identify with a faith. Woodhead (2013) designed a nationally representative survey of Great Britain which was administered by YouGov to probe this topic. It found that the top factors influencing the choice of a school in a local area are academic standards (77\%), location (58\%), discipline record (41\%) and ethical values (23\%).

Reasons to do with faith come well below these: 'Grounding of pupils in a faith tradition' $5 \%$ and 'transmission of belief in God' $3 \%$. There is remarkably little variation by faith when it comes to saying that academic standards count most: the largest proportion of Anglicans, Catholics, those of other faiths and those with 'no religion' say that academic standards are the most important consideration for them in choosing a school. As for the more faithrelated reasons for choosing a school, there is much more variation between faiths. 'Grounding of pupils in a faith tradition' is selected by $6 \%$ of Anglicans, $18 \%$ of Catholics, $8 \%$ of Muslims and $6 \%$ of Jews (this may reflect the relative importance given to faith socialisation in the home vis-à-vis in school, but it should be noted that sample sizes for the non-Christian faiths are small and merely indicative).

A second question on the same survey asked whether respondents would be likely to send a child to a faith school. Just under a quarter of the population as a whole said this was likely, compared with a just under a third of Anglicans, $57 \%$ of Catholics, $39 \%$ of Jewish people, $31 \%$ of Hindus, $41 \%$ of Muslims, $58 \%$ of Sikhs and $66 \%$ of Buddhists (again sample sizes are small for the non-Christian faiths). Only 7\% of those with 'no religion' would be likely to send a child to a faith school (Woodhead 2013; detailed secondary analysis of the same dataset has been carried out by Clements 2016 in relation to Catholics).

\section{Conclusion}

The sheer complexity of many faith schools' admissions criteria is one of the most striking findings of this article. Not only are these criteria complex and difficult to fulfil in the case of several of the faith schools - both Church and other faith - there is little consistency between schools. Some focus on parental faith, others on the child, and there are often multiple criteria. This problem is not confined to Leicester. According to the Schools Adjudicator's Annual Report in 2015, appeals over faith school admissions criteria accounted for 'a significant part of the adjudicator's workload' and most objections to these criteria were upheld partially or fully (Office of the Schools Adjudicator 2014, p.29). The adjudicator noted and criticised a complexity in some faith schools which makes it difficult for parents even to understand how the faith criteria would be satisfied - for example where 'multiple levels of [religious] practice' are demanded, far more levels than school place allocations can take into account (ibid, pp. 30f). Leicester illustrates some of these problems.

The research also illustrates how 'strict' religion and a measurable kind of active religious practice are given greater weight in faith school admissions than other kinds of adherence and more irregular practice. Parents and children who conform to the particular interpretation of the faith favoured by those who set the admissions criteria are advantaged relative to those who hold other interpretations, with no real right of appeal or protest. 
When it comes to the question of whether the existence of faith schools enhances choice for those looking to select a school in Leicester in 2016, the evidence is mixed. The main conclusion is that it depends what kind of religion - or 'no religion' - you have, and it depends on the quality and selection criteria of the faith schools available in a particular town or city. As we have seen, the largest faith groups in Leicester according to the 2011 census are Christian, 'no religion' and Muslim, followed by Hindu, and they are of highly variable quality in terms of attainment. In general, the growing number of faith schools in Leicester appears to give all except those with 'no religion' somewhat more choice, but it depends upon your faith and ability to meet the often complex selection criteria.

Muslims and Hindus have more choice than in the past if parents are willing to embrace the version of their faith embodied in the admissions criteria of their faith schools. The large number of Muslim fee-paying schools in Leicester indicates the demand for faith-based education in that community and, on its website, the Madani Federation outlines plans to open two new single sex secondary free schools for 2018. The Krishna Avanti Trust also has plans for an all age, 5-19, Hindu school (Leicester Mercury 2016b). At present, the Muslim state-schools are in practice not open to non-Muslim parents, so do not enhance choice more widely. Catholics also have more choice of good schools at primary and secondary levels, and may have more in the future if the Catholic Church goes ahead with plans to open new free schools. Anglicans have more choice of good schools only at primary level, and particularly if they are regular church attenders.

By contrast, the second largest group of parents and children in Leicester at the 2011 census (or the largest according to recent surveys) - those who say they have 'no religion' - do not benefit from the existence of faith schools unless they are prepared to fulfil the admissions criteria purely for the sake of getting a child into a faith school (most of those with 'no religion' are white British, so this only really applies for church schools). Our earlier national survey finds that only $7 \%$ say they would consider sending a child to a faith school. Thus, the one constituency that does not seem to gain any benefit from the growing number of faith schools in Leicester is 'no religion' parents and children, especially those from poorer backgrounds in areas where the local community school is underachieving, and who will not or cannot seek a place in a faith school. Since the number of those who report 'no religion' is growing steadily, this problem is unlikely to go away.

\section{$\underline{\text { Notes }}$}

1.The arguments in favour of faith schools include claims about their generally good academic standards, distinctive ethos and contribution to community cohesion and assert the right of parents to educate their child in their faith and the benefits of parental choice (Oldfield, Hartnett, and Bailey 2013; Church of England Archbishops' Council. Education Division. 2009; Department for children schools and families (Dcsf) 2007). In England as a whole, faith schools tend to be over-represented at the top of the primary schools league tables for test results at the end of key stage 2 (Gov.uk 2015) and on average, a slightly higher percentage of their pupils gain 5 or more good GCSE grades (Long and Bolton 2015, p. 18). Arguments against faith schools include the claim that they are divisive, separating children not only by religion but also socially and sometimes by ethnic group, that the 
exercise of parental choice increases inequalities in the education system, and that instilling specific religious beliefs and values is a matter for parents and the community not for statefunded schools (Accord Coalition 2017; Berkeley, R. with research by Vy, S 2008; British Humanist Association 2006).

2.All the Ofsted and denominational reports for Anglican and Roman Catholic faith schools referred to in this report can be accessed through the relevant diocesan website. The Nottingham Roman Catholic Diocese Education website lists both reports under the school name at http://www.nottingham-diocesan-centre.org. uk/index.php/inspectionintroduction/new-school-directory. The Diocese of Leicester Board of Education website has a list of Church of England schools (Leicester followed by name of school) with links to each school website on which the latest Ofsted and Section 48/denominational inspection reports will be found. See http:// www.leicester-dbe.com/our-church-schools-andacademies/ 


\section{References}

Accord Coalition. 2017. Databank of Independent Evidence on Faith Schools

http://accordcoalition.org.uk/research/

AMS UK Inspection reports Section 48 http://ams-uk.org/services/section-48-inspections/ AMS UK (Association of Muslim Schools) Directory of schools http://directory.amsuk.org/schools full.asp

AMS UK. 2014. Madani Girls School Inspection Report 7 October 2014 [section 48 report]. http://www.madani.leicester.sch.uk/mgs/images/Madani\%20Girls\%20School\%20\%20Section\%2048\%20Report\%20[October\%202014].pdf

Berkeley, R. with research by Vy, S. 2008. Right to divide. Faith schools and community cohesion. A Runnymede Report. Runnymede Trust.

http://www.runnymedetrust.org/uploads/publications/pdfs/RightToDivide-2008.pdf BBC Leicester. 2007. Is/amic School Criticised

http://www.bbc.co.uk/leicester/content/articles/2007/10/03/islamic school feature.shtml British Humanist Association. 2006. Briefing 2006/4 Faith Schools. Update. https://humanism.org.uk/wp-content/uploads/BHA-Briefing-Faith-schools-update.pdf Church of England Archbishops' Council. Education Division.2009. Strong schools for strong communities. Reviewing the impact of Church of England schools in promoting community cohesion. Nov.2009.

https://www.churchofengland.org/media/1204726/strong\%20schools\%20for\%20strong\%20 communities\%20-\%20cofe\%20report\%20final.pdf

Bullivant, S. 2017. 'The “no religion” population of Britain'. Catholic Research Forum Reports 3. Benedict XV1 Centre. St Mary's University Twickenham. 
Clarke, C. and Woodhead, L. 2015. A New Settlement: Religion and Belief in Schools.

Westminster Faith Debates.

Darul Uloom Leicester Institute of Higher Islamic Education

www.darululoomleicester.org/

Department for children schools and families (Dcsf) 2007. Faith in the system. The role of schools with a religious character in English education and society. Nottingham: Dcsf Publications. http://www.religionlaw.co.uk/FaithlnTheSystem.pdf Department for Education 2016 Schools that work for everyone. Government consultation. Department for Education 2017 House prices and schools: do houses close to the best performing schools cost more? Ad hoc research note. March 2017.

https://www.gov.uk/government/uploads/system/uploads/attachment data/file/600623/H ouse prices and schools.pdf

Diocese of Leicester Diocesan Board of Education http://www.leicester-dbe.com/ourchurch-schools-and-academies/

Gov.uk School and College Performance Tables 2015

http://www.education.gov.uk/schools/performance/

Emmanuel School http://www.leicesterchristianschool.org/

English Martyrs' Catholic School Admissions Policy

http://www.englishmartyrs.org/index.php/admissions/admissions-policy

Fair Schools Admissions Campaign.2015).An Unholy Mess. How virtually all religiously selective state schools in England are breaking the law A BHA report for the Fair Admissions Campaign. London: BHA. http://fairadmissions.org.uk/wp-content/uploads/2015/09/An$\underline{\text { Unholy-Mess.pdf }}$ 
Falcons Primary School. Schools Admissions Policy, Oversubscription Criteria and Arrangements. http://www.falconsprimary.org/ (under Admissions Policy)

Falcons Primary School Section 48 School report 28.02.2017

http://www.falconsprimary.org/Inspection-Reports/

Francis B. and Hutchings M. 2013 Parent Power? Using money and information to boost children's chances of educational success. The Sutton Trust

http://www.suttontrust.com/wp-content/uploads/2014/08/1parentpower-final.pdf Heelas P. and Woodhead L. 2005 The Spiritual Revolution: Why Religion is Giving Way to Spirituality. Oxford: Blackwell.

Imam Muhammad Adam Institute Secondary School 2016 Ofsted Inspection Report http://reports.ofsted.gov.uk/inspection-reports/find-inspectionreport/provider/ELS/137561 Independent Schools Inspectorate.2011.Leicester Grammar School Standard Inspection http://www.isi.net/school/leicester-grammar-school-trust-6640?results=true Independent Schools Inspectorate.2015a).Leicester High School for Girls Integrated Inspection http://www.isi.net/school/leicester-high-school-for-girls-6641 Independent Schools Inspectorate. 2015b). Ratcliffe College Integrated Inspection http://www.isi.net/school/ratcliffe-college-6822 Jameah Girls Academy http://www.jgacademy.org.uk/ Jivraj, S. and Finney, J. 2013. Geographies of Diversity in Leicestershire. Leicestershire County Council. Local dynamics of diversity: evidence from the 2011 census. Prepared by ESRC Centre on Dynamics of Ethnicity (CoDE), University of Manchester. Krishna Avanti Primary School http://www.kapsleicester.org.uk/ 
Leicester City Council.2015a.Council Transport to school.

https://www.leicester.gov.uk/schools-and-learning/school-and-colleges/transport-to-school Leicester City Council 2015b. Briefing on the English index of multiple deprivation. https://www.leicester.gov.uk/media/181190/indices-of-deprivation-in-leicester.pdf Leicester City Council.2016a).Applying for your child's primary/infant/junior school place 2016/17.

http://www.leicester.gov.uk/media/180310/primaryadmissionsbooklet2016-17.pdf Leicester City Council.2016b. .Applying for your child's secondary school place 2016/17. http://www.leicester.gov.uk/media/180309/secondaryadmissionsbooklet2016-17.pdf Leicester High School for Girls http://www.leicesterhigh.co.uk/ Leicester Mercury 14 November 2016 Tudor Grange Samworth Academy has the worst truancy rate in Leicester http://www.leicestermercury.co.uk/tudor-grange-samworthacademy-has-the-worst-truancy-rate-in-leicester/story-29893749-detail/story.html Leicester Mercury 15 May 2017 'New Hindu school for five to 19 year olds could open next year' http://www.leicestermercury.co.uk/new-hindu-school-open-year/story-29265767detail/story.html Levitt M. 1996. Nice When They are Young: Contemporary Christianity in Families and Schools. Aldershot:Avebury.

Long, R. and Bolton, P. 2015.Faith Schools FAQs. House of Commons Library Briefing Paper Number 0697214 October 2015 detail/story.html http://researchbriefings.parliament.uk/ResearchBriefing/Summary/SN06972 Long R., Foster D. and Roberts N. 2017. Grammar schools in England. House of Commons Library. Briefing paper Number 7070. 9 March 2017. http://researchbriefings.files.parliament.uk/documents/SN07070/SN07070.pdf 
Madani Girls School.2016 Admissions Arrangements 2017-18

http://www.madani.leicester.sch.uk/mgs/images/admissions-policy-2017-2018-MGS.pdf

Madani School Mission Statement [under Information: Mission statement]

http://www.madani.leicester.sch.uk/

National Archive.2011. .Department for Education Choice Advisers Support and Quality

Assurance Network .2/2/11

http://webarchive.nationalarchives.gov.uk/20110202133311/choiceadvice.dcsf.gov.uk/dfes

2/modules.php?name=home

Nottingham Roman Catholic Diocese Education [click on school name for section 48 and

Ofsted inspection reports] http://www.nottingham-diocesan-

centre.org.uk/index.php/inspection-introduction/new-school-directory.

Office of the Schools Adjudicator.2015a).Annual Report September 2014 to August 2015.

https://www.gov.uk/government/publications/osa-annual-report

Office of the Schools Adjudicator .2015b).Case reference STP 623. A statutory proposal to extend the age range for Madani Boys' School and Madani Girls' school, Leicester

Date of Adjudicator's Determination: 20 November 2015

https://www.gov.uk/government/uploads/system/uploads/attachment data/file/478748/S

TP623 Madani_Schools Leicester City_-20 November_2015.pdf

Ofsted.2013. Madani Girls School Inspection Report

http://reports.ofsted.gov.uk/inspection-reports/find-inspection-

report/provider/ELS/129645

Ofsted.2015a.Al-Aqsa School Inspection Report http://reports.ofsted.gov.uk/inspectionreports/find-inspection-report/provider/ELS/134809

Ofsted. 2015b. Emmanuel Christian School Independent School Inspection Report 
http://reports.ofsted.gov.uk/inspection-reports/find-inspection-

report/provider/ELS/134595

Ofsted.2015c. Jameah Girls' Academy Inspection Report

https://reports.ofsted.gov.uk/inspection-reports/find-inspection-

report/provider/ELS/133349

Ofsted.(2015d.Leicester Islamic Academy Inspection Report

http://reports.ofsted.gov.uk/inspection-reports/find-inspection-

report/provider/ELS/120335

Ofsted. 2015e. Leicester International School Inspection Report

http://reports.ofsted.gov.uk/inspection-reports/find-inspection-

report/provider/ELS/134905

Ofsted.2016a. Al Islamia Institute for Education http://reports.ofsted.gov.uk/inspection-

reports/find-inspection-report/provider/ELS/135390

Ofsted. 2016b. Imam Ghazali Academy Inspection March 2016

https://reports.ofsted.gov.uk/provider/files/2563385/urn/141958.pdf

Ofsted. 2016c. Madani Boys School Inspection Report

http://reports.ofsted.gov.uk/inspection-reports/find-inspection-

report/provider/ELS/138869

Oldfield, E. Hartnett, L. and Bailey, E. 2013. More than an Educated Guess:

Assessing the evidence on faith schools. London: Theos

Ratcliffe College http://ratcliffe-college.co.uk/

Telegraph GCSE Results 2015 Independent Schools Table. 29 August 2015.

http://www.telegraph.co.uk/education/leaguetables/11825016/GCSE-results-2015-

$\underline{\text { Independent-schools-table.html }}$ 
Tudor Grange Samworth Academy http://www.samworth.tgacademy.org.uk/)

Tudor Grange Academy Trust http://www.tgacademy.org.uk/

Wilshaw, M. 2015 Advice note from Sir Michael Wilshaw, Her Majesty's Chief Inspector, on the inspection of schools previously inspected by the Bridge Schools Inspectorate 24 Ofsted.

24 November 2015.

https://www.gov.uk/government/publications/bridge-schools-inspectorate-ofsted-advice$\underline{\text { note }}$

Wilshaw, M. 2016 Letter to Education Secretary about segregation in independent faith schools Ofsted. 27 April 2016

https://www.gov.uk/government/publications/sir-michael-wilshaw-letter-about$\underline{\text { segregation-in-independent-faith-schools }}$

Woodhead, L. 2013 'New Poll Shows the Debate on Faith Schools isn't Really about Faith'. http://faithdebates.org.uk/wp-content/uploads/2013/10/WFD-Faith-Schools-Press-

$\underline{\text { Release.pdf }}$

Woodhead, L. 2016 The Rise of 'No Religion' in Britain: The Emergence of a Cultural Majority, Journal of the British Academy, 4, 245-61. 
Appendix 1. Leicester City State-funded Primary Schools with a Religious Designation (1)

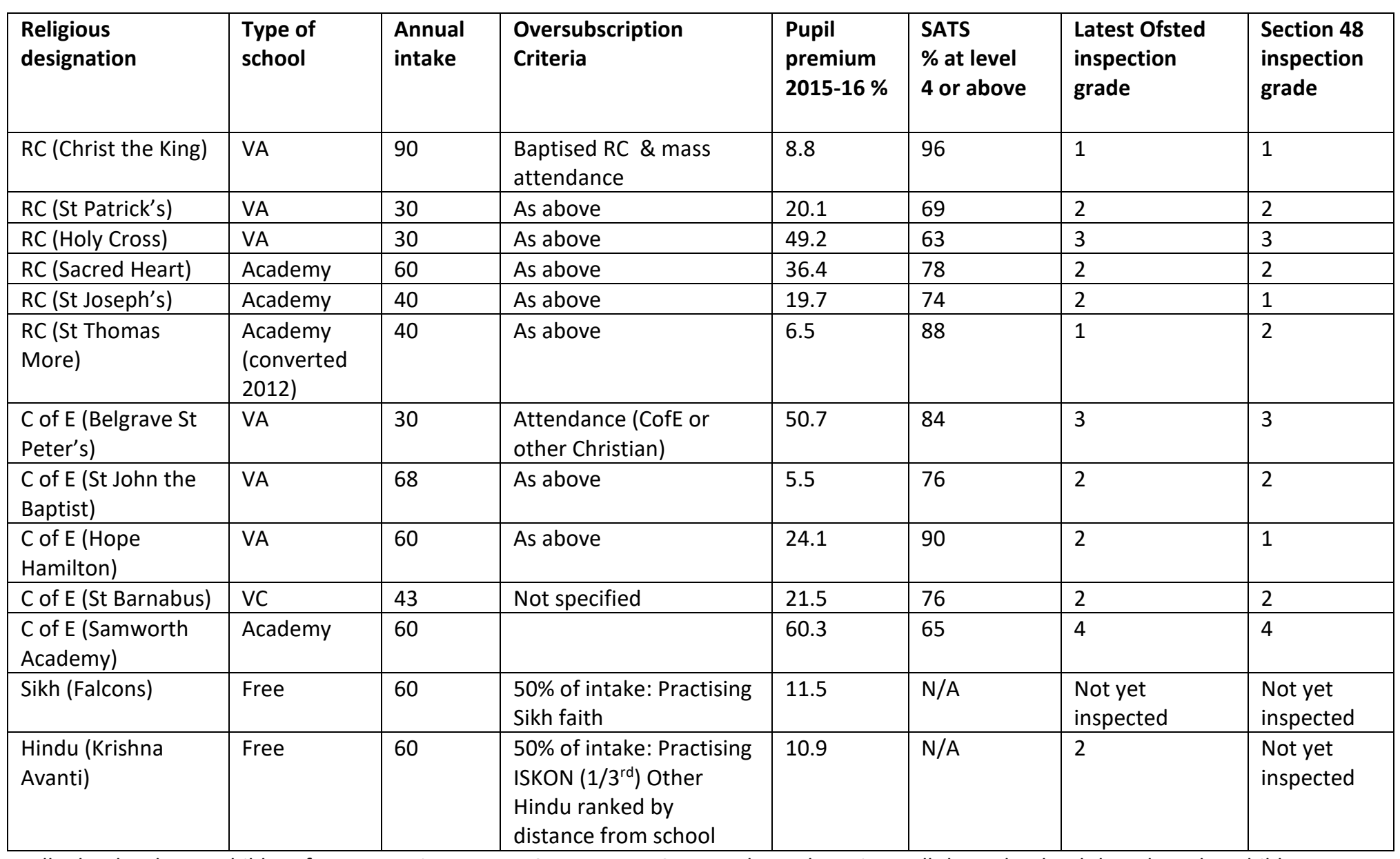

All schools educate children from reception to year 6, ages 4-11. Samworth Academy is an all through school that also takes children up to age 16. 
Appendix 2: Leicester City State-funded Secondary Schools with a Religious Designation

\begin{tabular}{|c|c|c|c|c|c|c|c|c|c|c|c|}
\hline $\begin{array}{l}\text { Religious } \\
\text { designation }\end{array}$ & $\begin{array}{l}\text { Type of } \\
\text { school }\end{array}$ & $\begin{array}{l}\text { Age } \\
\text { range }\end{array}$ & $\begin{array}{l}\text { Faith } \\
\text { admissions } \\
\text { criteria }\end{array}$ & $\begin{array}{l}\text { \% eligible for } \\
\text { deprivation } \\
\text { pupil premium } \\
2015-16\end{array}$ & $\begin{array}{l}\text { 5+ GCSEs A-C \% } \\
\text { with English \& } \\
\text { Maths (2015) }\end{array}$ & $\begin{array}{l}\text { English } \\
\text { Bacc }\end{array}$ & $\begin{array}{l}\text { Ranking on } \\
\text { GCSE results } \\
(1)\end{array}$ & $\begin{array}{l}\text { Ofsted } \\
\text { inspection } \\
\text { grade (2) }\end{array}$ & $\begin{array}{l}\text { Section } 48 \\
\text { inspection } \\
\text { grade (2) }\end{array}$ & $\begin{array}{l}\text { Making } \\
\text { expected } \\
\text { progress } \\
\text { English\% }\end{array}$ & $\begin{array}{l}\text { Making } \\
\text { expected } \\
\text { progress } \\
\text { Maths } \\
\% \\
\end{array}$ \\
\hline $\begin{array}{l}\text { RC (English } \\
\text { Martyrs') }\end{array}$ & VA & $11-18$ & Baptised RC & 23.2 & 60 & 22 & 6th & 2 & 1 & 64 & 68 \\
\hline RC (St Paul's) & VA & $11-18$ & As above & 23.8 & 56 & 13 & 7 th & 3 & 1 & 66 & 69 \\
\hline $\begin{array}{l}\text { C of E (Tudor } \\
\text { Grange) }\end{array}$ & Academy & $4-16$ & None & 67.9 & 28 & 4 & 17th & 4 & 4 & 49 & 50 \\
\hline $\begin{array}{l}\text { Muslim girls } \\
\text { (Madani) }\end{array}$ & VA & $11-16$ & $\begin{array}{l}\text { Child's belief } \\
\text { \& practice }\end{array}$ & 40.7 & 78 & 17 & $1 s t$ & 2 & 1 & 81 & 88 \\
\hline $\begin{array}{l}\text { Muslim boys } \\
\text { (Madani) }\end{array}$ & VA & $11-16$ & As above & 37.3 & 55 & 5 & 8th & 2 & 1 & 86 & 57 \\
\hline
\end{tabular}

(1) Ranking is the school's position on 5+ GCSEs grades A-C including English and Maths out of 18 Leicester City schools (academies, VA and community schools, not independent schools) for which key stage data was available (Gov.uk School and College Performance Tables, Leicester 2015).

(2) Inspection grades are: 1 = outstanding 2= good 3= requires improvement (previously 'satisfactory') 4= inadequate 
Appendix 3: Leicester City State-funded secondary schools (no religious designation).

\begin{tabular}{|c|c|c|c|c|c|c|c|c|c|c|}
\hline Name & $\begin{array}{l}\text { Type of } \\
\text { school }\end{array}$ & $\begin{array}{l}\text { Age } \\
\text { range }\end{array}$ & Specialism & $\begin{array}{l}\text { \% eligible for } \\
\text { deprivation pupil } \\
\text { premium } \\
2015-16\end{array}$ & $\begin{array}{l}\text { 5+ GCSEs A*- } \\
\text { C (\%) } \\
\text { includes } \\
\text { English \& } \\
\text { Maths } \\
(2015)\end{array}$ & $\begin{array}{l}\text { English } \\
\text { Bacc }\end{array}$ & $\begin{array}{l}\text { Ranking on } \\
\text { GCSE results } \\
(1)\end{array}$ & $\begin{array}{l}\text { Ofsted } \\
\text { inspection } \\
\text { grade (2) }\end{array}$ & $\begin{array}{l}\text { Making } \\
\text { expected } \\
\text { progress } \\
\text { English\% }\end{array}$ & $\begin{array}{l}\text { Making } \\
\text { expected } \\
\text { progress } \\
\text { Maths } \\
\%\end{array}$ \\
\hline Babington & Trust & $11-16$ & Sport & 49.1 & 45 & 17 & 14th & 1 & 79 & 61 \\
\hline Beaumont Leys & Community & $11-16$ & & 43.6 & 49 & 7 & 10th & 2 & 73 & 56 \\
\hline Crown Hills & Community & $11-16$ & Sport & 34.3 & 53 & 16 & 9th & 2 & 65 & 73 \\
\hline Fulhurst & Trust & $11-16$ & & 50.8 & 35 & 4 & 15th & 2 & 59 & 60 \\
\hline Hamilton & Community & $11-16$ & & 35.7 & 25 & 8 & 18th & 2 & 53 & 41 \\
\hline Judgemeadow & Community & $11-16$ & Languages & 28 & 62 & 39 & 5 th & 2 & 80 & 68 \\
\hline Moat & Community & $11-16$ & Science & 43.8 & 49 & 7 & 11th & 2 & 63 & 59 \\
\hline New College & Trust & $11-18$ & & 58 & 35 & 6 & 16th & 2 & 59 & 50 \\
\hline Rushley Mead & Academy (3) & $11-16$ & Sport \& science & 31.7 & 66 & 47 & 2nd & 1 & 83 & 78 \\
\hline $\begin{array}{l}\text { Sir Jonathan } \\
\text { North }\end{array}$ & Community & $\begin{array}{l}11-16 \\
\text { Girls }\end{array}$ & $\begin{array}{l}\text { Visual arts, } \\
\text { science, maths } \\
\text { applied learning }\end{array}$ & 31.2 & 63 & 29 & 4th & 1 & 65 & 91 \\
\hline $\begin{array}{l}\text { Soar Valley } \\
\text { College }\end{array}$ & Community & $11-16$ & Maths & 35.5 & 65 & 28 & $3 r d$ & 1 & 78 & 81 \\
\hline $\begin{array}{l}\text { City of Leicester } \\
\text { College }\end{array}$ & Community & $11-18$ & $\begin{array}{l}\text { Business \& } \\
\text { enterprise }\end{array}$ & 35 & 48 & 22 & 12th & 3 & 61 & 60 \\
\hline $\begin{array}{l}\text { The Lancaster } \\
\text { School }\end{array}$ & Community & $\begin{array}{l}\text { 11-16 } \\
\text { Boys }\end{array}$ & Sports & 34.9 & 46 & 13 & 13th & 4 & 54 & 59 \\
\hline
\end{tabular}

(1) Ranking is the school's position on 5+ GCSEs grades A-C including English and Maths out of 18 Leicester City schools (academies, VA and community schools, not independent schools) for which key stage data was available (Gov.uk School and College Performance Tables, Leicester 2015).

(2) Inspection grades are: 1 = outstanding 2= good 3= requires improvement (previously 'satisfactory') 4= inadequate

(3) Still described as a community school in Leicester City Council 2016-17 admissions booklet. 
Appendix 4: Proportions of state-funded faith and non-faith schools in England

Based on the Department for Education's Statistics First Release: Schools, pupils and their characteristics: January 2014 (SFR 15/2014, Table 2c). https://www.gov.uk/government/uploads/system/uploads/attachment_data/file/335176/2014_SPC_SFR_Text_v101.pdf

\begin{tabular}{|c|c|c|c|c|}
\hline & Primary & Secondary & Total State & Independent \\
\hline Total $(24,347)$ & 16,788 & 3,329 & 20,117 & 2,411 \\
\hline \multicolumn{5}{|l|}{ Of which:- } \\
\hline $\begin{array}{l}\text { No religious } \\
\text { character }\end{array}$ & 10,577 & 2,696 & 13,273 & \\
\hline $\begin{array}{l}\text { \% non-faith } \\
\text { schools }\end{array}$ & $63 \%$ primary & $\begin{array}{l}81 \% \\
\text { secondary }\end{array}$ & & \\
\hline Faith schools & 6,211 & 633 & 6,844 & \\
\hline $\begin{array}{l}\text { \% faith } \\
\text { schools }\end{array}$ & $\begin{array}{l}37 \% \\
\text { primary }\end{array}$ & $\begin{array}{l}19 \% \\
\text { secondary }\end{array}$ & & \\
\hline \multicolumn{5}{|l|}{ Of which:- } \\
\hline CofE & $\begin{array}{l}4,394 \\
\text { (VC 2,235) }\end{array}$ & $\begin{array}{l}207 \\
\text { (VC 26) }\end{array}$ & 4,601 & 1,000 \\
\hline Catholic & 1,662 & 324 & 1,986 & 150 \\
\hline Other Christian & 101 & $\begin{array}{l}77 \\
\text { (VC51) }\end{array}$ & 178 & \\
\hline $\begin{array}{l}\text { \% Christian } \\
\text { schools }\end{array}$ & $\begin{array}{l}99.1 \% \\
\text { primary }\end{array}$ & $\begin{array}{l}96.1 \% \\
\text { secondary }\end{array}$ & & \\
\hline Jewish & 36 & 12 & 48 & 60 \\
\hline Muslim & 9 & 9 & 18 & 140 \\
\hline Sikh & 5 & 3 & 8 & \\
\hline
\end{tabular}




\begin{tabular}{|l|l|l|l|l|}
\hline $\begin{array}{l}\text { \% non- } \\
\text { Christian schools }\end{array}$ & $\begin{array}{l}0.9 \% \\
\text { primary }\end{array}$ & $\begin{array}{l}3.9 \% \\
\text { secondary }\end{array}$ & & \\
\hline Other & 4 & 1 & 5 & \\
\hline
\end{tabular}

Note. These categorisations are not always straightforward and the recent development of 'academies' (which includes all 'free schools') complicates the situation further. For example, the table includes about 400 free schools which are either open or have been approved, and whose number is increasing 